\title{
MIX DESIGN FOR OIL-PALM-BOILER CLINKER (OPBC) CONCRETE
}

\author{
M. A. Mannan ${ }^{1}$ and, K. Neglo ${ }^{2}$ \\ ${ }^{1}$ Civil Engineering Program, \\ School of Engineering and Information Technology Universiti \\ Malaysia Sabah (UMS), 88999 Kota Kinabalu, Sabah, Malaysia \\ ${ }^{2}$ Département de génie Civil, Université de Lomé, B.P. 1515 Lomé Togo
}

\begin{abstract}
An experimental investigation was conducted in mix design for lightweight concrete using OilPalm-Boiler Clinker (OPBC) as coarse aggregate. ACI mix design as used for normal weight concrete and mix design methods as used for lightweight concrete were employed to obtain the target compressive strength at 28-day and was found to be lower than the target strength for $O P B C$ concrete. It was confirmed that the above established mix design methods couldn't be used in this new OPBC concrete. Through trial mixes, the acceptable mix designs of this new concrete were obtained. The properties obtained from the acceptable mix designs were slumps of 40 to $100 \mathrm{~mm}$, demoulded densities of 1845 to $1980 \mathrm{~kg} / \mathrm{m}^{3}$ and the 28-day compressive strengths of 27 to 35MPa.
\end{abstract}

Keywords: Oil-Palm-Boiler Clinker (OPBC), Solid Waste, Mix Design, Lightweight Concrete, Compressive Strength

\section{INTRODUCTION}

Due to increasing cost of raw materials and the continuous depletion of natural resources, researchers are focusing more towards utilisation of solid wastes and by-products, which are discharged from agriculture, industry and municipality. These solid wastes and by-products, when properly processed have shown to be effective as construction materials and can readily meet design specifications. Concrete using agricultural waste, which is abundant in agro-based countries, presents an interesting alternative to the conventional concrete materials (Tay 1990; Mannan and Ganapathy 2004).

Countries like Malaysia, Indonesia, Thailand, Nigeria, Côte d'Ivoire, Cameroon, Benin,
Togo, Ghana, etc. produce palm oil as an agrobased industry. Palm oil tree is indigenous in West Africa, with natural stands occurring along about $480 \mathrm{~km}$ wide coastal belt ranging from the Gambia to Angola. Oil palm also extends eastward through central Africa and into eastern Africa. The African countries which hold large areas covered by oil palms are Nigeria (2.6 million ha, $80 \%$ of the area comes from dispersed smallholders who harvest semi-wild plants and use manual processing techniques), Guinea (310,000ha), Democratic Republic of Congo (formerly Zaire) (220,000ha), Cote d'Ivoire $(190,200$ ha divided in two different sectors: smallholders with a total of $135,000 \mathrm{ha}$, and private enterprises with 55,200ha), Ghana $(125,000$ ha mostly under the nucleus estate 


\section{Mannan and Neglo}

model, which implies a large plantation surrounded by smaller plantations established in local farmers' lands), Cameroon $(80,000$ ha di-

\section{Table 2: Signicative regression parameters}

vided in three different sectors: large scale industrial plantations with some 58,000ha; village plantations comprising 12,000ha and "Informal" plantations covering some 10,000 ha), and smaller areas in Benin, Burundi, Central African Republic, Republic of Congo, Equatorial Guinea, Gabon, Gambia, Guinea Bissau, Liberia, Senegal, Tanzania, Togo, and Uganda (USDA, 2002).

At present, Malaysia has become the world's largest producer and exporter of palm oil, with oil palm planted in over 4.05 million hectares of land (MPOB, 2006). Sabah, Malaysia is the largest oil palm planted state, with coverage of about 1.2 million hectares (Wahid, 2006). Usually, the fibber and shell are used as boiler fuel to produce steam to generate electricity for the oil palm mill operation. This burnt solid waste is called Oil-Palm-Boiler clinker (OPBC). Based on a survey, it is estimated that about $45,750 \mathrm{~m}^{3}$ OPBC is discharged from oil palm mill in Sabah annually. OPBC is a solid-waste and has disposal problem. Moreover construction industry needs more materials in concrete production. Environmental considerations hinder the supply of natural aggregate. Therefore the OPBC as renewable resource can be high potential as an alternative to non-renewable natural stone aggregate and it can fulfil the high demand in construction industry.

The objective of this paper is to investigate the mix design procedure suitable for Oil-PalmBoiler Clinker (OPBC) concrete in structural purposes. Concrete mix design can be defined as the selection of the most suitable materials for optimum engineering properties with economical consideration. Mix design methods of normal weight concrete are generally difficult to use for lightweight concrete production. The lack of accurate value of absorption, specific gravity and free moisture content in the aggregate make it difficult to apply the water/cement ratio correctly for mix proportioning. The mix design is done taking into account the strength required, density and workability requirement for the specific uses of lightweight concrete. Structural lightweight concrete is defined as having an oven dry density of less than 2000 $\mathrm{kg} / \mathrm{m}^{3}$ (ENV 1992). Aggregates with particle density of less than $2000 \mathrm{~kg} / \mathrm{m}^{3}$ or a dry loose bulk density less than $1200 \mathrm{~kg} / \mathrm{m}^{3}$ are defined as lightweight aggregate (BSI Document 92/17688, 1992). Structural lightweight concrete used for structural purposes must have a minimum compressive strength of $17 \mathrm{MPa}$.

\section{Selection criteria for solid waste in concrete making}

The current trend in environmental control and solid waste disposal is focused towards effective utilisation of agricultural, municipal and industrial solid wastes by applying more legal and moral restrictions on waste disposal. As a result, attention has been paid to the utilisation of certain types of solid wastes as construction materials. Since construction industry always deals with large-scale projects and needs a great deal of materials, the major technical properties of solid wastes must be primarily understood before incorporation and use (Mannan, 2001; Nontananandh, 1990). In concrete making, the ingredients must fall either under binder (like cement, fly ash, silica fume, slag) group or filler group (fine and coarse aggregates make body of the structure). Normally, binder occupies about $20 \%$ volume in concrete and the rest of the volume is filled with aggregates.

The feasibility of solid waste utilisation depends on many factors, including the cost/ benefit analysis etc. (economic, social and environmental cost). The economic gain is mainly due to the cost of solid waste, which are usually either less than that of the natural material or much less than the cost of production of a new material. Environmental benefits are that natural resources and energy can be conserved and that the quantum of discharged waste into the environment is reduced. Optimum economic benefit will be achieved when solid wastes produced meet the following criteria (Mannan, 
2001; Nontananandh, 1990):

- Locally available in large quantity as filling material

- Low unit cost but high quality which saves on total cost

- $\quad$ No processing cost or minimum processing cost if additional processing necessary

- No health hazard during handling

- Easy to handle and store

- No degradation on resulting product or environment

Environmental-friendly renewable resource for concrete production.

- The major factors to be considered for the use of solid wastes for developing new construction materials in concrete making are:

- Effect on workability of fresh concrete

- Influence on strengths of hardened concrete

- Influence on durability of hardened concrete.

\section{MATERIALS AND PROPERTIES}

The ordinary Portland cement (ASTM type I), river sand, OPBC aggregates, potable water and super plasticizer (Type-F naphthalene sulphonate formaldehyde condensate) were used. Full water curing was employed for up to 28 days. Properties of materials are given in Table 1. A sample of OPBC aggregates is shown in Figure 1. The gradation of OPBC aggregates and river sand is shown in Figure 2.

Aggregates are classified as lightweight aggregates when having a specific gravity (S.G.) less than 2.2 and bulk density less than $1200 \mathrm{~kg} / \mathrm{m}^{3}$ (BSI Document 92/17688, 1992). The specific gravity and bulk density observed for OPBC aggregates were 1.68 and $805 \mathrm{~kg} / \mathrm{m}^{3}$ respectively, and hence it was in the range of lightweight aggregates.

\section{Mix design procedure for OPBC concrete}

Several established methods were adopted in the OPBC concrete mix design. They were ACI mix design method as used for normal weight concrete and two other mix design methods as used for lightweight concrete as mentioned in references (Shetty 2008; Short and Kinniburgh, 1978). Mix orders that from ACI-1 to ACI-4 as shown in Table 2 are based on ACI mix method. The obtained 28-day compressive strengths of OPBC concrete in the range of 13.0 to $14.0 \mathrm{MPa}$ were far below the targeted 28 -day strength. Four mixes are enough for conclusion. The demoulded densities noted were more than $2000 \mathrm{~kg} / \mathrm{m}^{3}$, which is as an indication of concrete density. The slump values obtained were between zero and $30 \mathrm{~mm}$. The super plasticizer was used in all the mixes but it could not increase the workability of OPBC concrete. In these mixes and the others, all concrete cubes are of $100 \mathrm{mmx} 100 \mathrm{~mm} \times 100 \mathrm{~mm}$ in size and the results of compressive strength are average of the three cube samples.

In Table 3, the mixes from AS-1 to AS-6 of OPBC concrete were based on the mix design for lightweight concrete as suggested by Short and Kinniburgh (1978).

The obtained demoulded densities in the range of 2105 to $2215 \mathrm{~kg} / \mathrm{m}^{3}$ were more than 2000 $\mathrm{kg} / \mathrm{m}^{3}$ except for mix ST-1 having demoulded density of $1744 \mathrm{~kg} / \mathrm{m}^{3}$. However, the obtained 28-day compressive strengths were in the range of $10.0 \mathrm{MPa}$ to $19.5 \mathrm{MPa}$ far below the targeted

Table 1: Properties of OPBC and river sand

\begin{tabular}{lll}
\hline Property & OPBC & River sand \\
\hline Maximum size $(\mathrm{mm})$ & 20 & 1.18 \\
Specific gravity (SG) & 1.68 & 2.60 \\
Bulk density (compacted), $\left(\mathrm{kg} / \mathrm{m}^{3}\right)$ & 805 & 1513 \\
Water absorption for 24 hours, (\%) & 2.67 & 0.95 \\
Aggregate impact value, AIV (\%) & 29.64 & - \\
Fineness modulus, FM & 5.82 & 1.72 \\
\hline
\end{tabular}


114 Mannan and Neglo

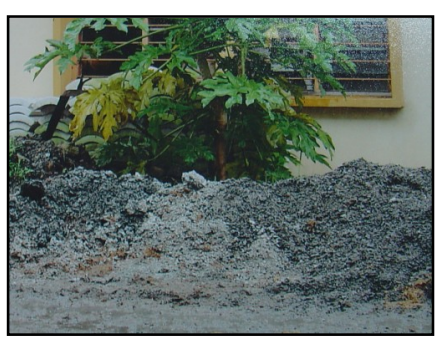

a- OPBC left at oil palm mill area

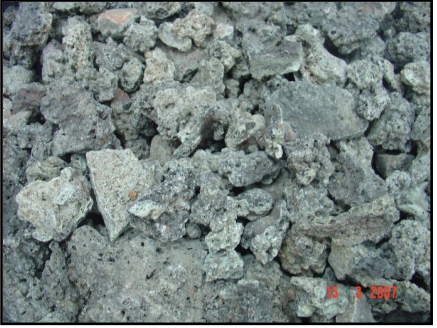

b- OPBC with big lump

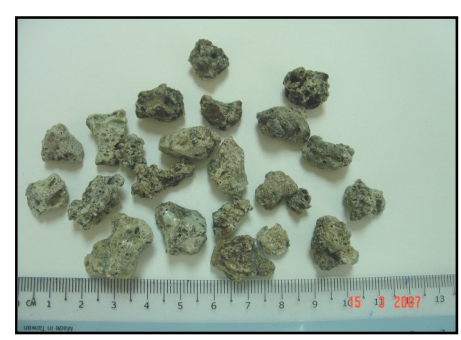

c- Prepared OPBC aggregate for concrete making

Fig. 1: OPBC aggregates

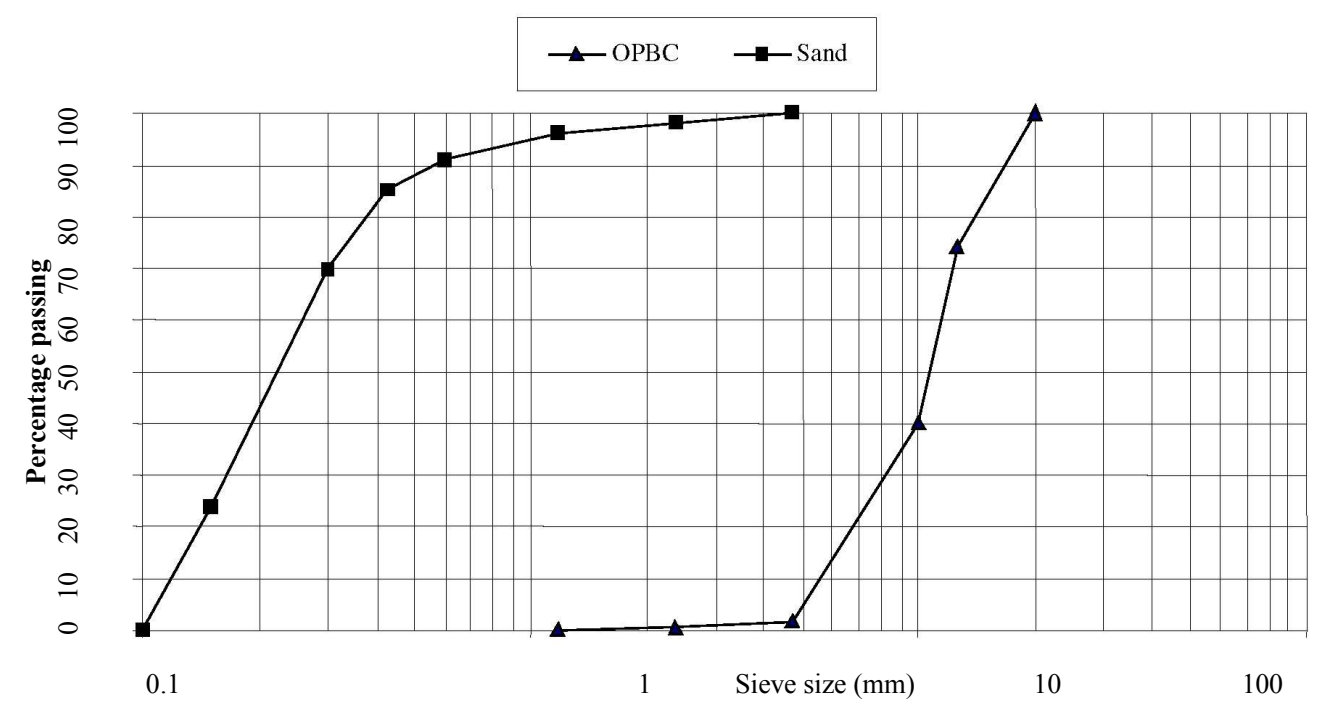

Fig.2: Gradation of OPBC and river sand

Table 2: Mix design for OPBC concrete according to ACI mix design

\begin{tabular}{|c|c|c|c|c|c|c|c|c|c|c|}
\hline \multirow[t]{2}{*}{$\begin{array}{l}\text { Mix } \\
\text { no. }\end{array}$} & \multirow{2}{*}{$\begin{array}{l}\text { Cement } \\
\mathrm{kg} / \mathrm{m}^{3}\end{array}$} & \multicolumn{3}{|c|}{$\begin{array}{c}\text { Mix proportion (by } \\
\text { weight) }\end{array}$} & \multirow[t]{2}{*}{$\mathbf{w} / \mathbf{c}$} & \multirow[t]{2}{*}{ Sp } & \multirow{2}{*}{$\begin{array}{l}\text { Slump } \\
(\mathbf{m m})\end{array}$} & \multirow{2}{*}{$\begin{array}{c}\text { De- } \\
\text { moulded } \\
\text { density } \\
\left(\mathrm{kg} / \mathrm{m}^{3}\right)\end{array}$} & \multirow{2}{*}{$\begin{array}{c}\text { Targeted } \\
\text { comp. st. } \\
\text { (28 days) } \\
\mathrm{MPa}\end{array}$} & \multirow{2}{*}{$\begin{array}{l}\text { Obtained } \\
\text { comp. st. }(28 \\
\text { days) MPa }\end{array}$} \\
\hline & & C & $\mathbf{S}$ & OPBC & & & & & & \\
\hline ACI-1 & 350 & 1 & 3.19 & 0.60 & 0.50 & 1.70 & 20 & 2131 & 25.0 & 13.5 \\
\hline ACI-2 & 350 & 1 & 3.19 & 0.60 & 0.50 & 1.71 & 30 & 2238 & 25.0 & 13.0 \\
\hline ACI-3 & 450 & 1 & 3.19 & 0.60 & 0.50 & 1.70 & 0 & 2148 & 25.0 & 14.0 \\
\hline ACI-4 & 450 & 1 & 3.19 & 0.60 & 0.50 & 1.71 & 0 & 2255 & 25.0 & 14.0 \\
\hline
\end{tabular}

Note: C-Cement, S-Sand, OPBC-Oil Palm Boiler Clinker, Sp-Super plasticizer (litre/100 kg cement) 
Mix design for oil-palm-broiler clinker...

Table 3: Mix design for OPBC concrete according to method in ref. (Short et al. 1978)

\begin{tabular}{|c|c|c|c|c|c|c|c|c|c|c|}
\hline \multirow{2}{*}{$\begin{array}{l}\text { Mix. } \\
\text { No. }\end{array}$} & \multirow[t]{2}{*}{$\begin{array}{l}\text { Cement } \\
\mathrm{kg} / \mathrm{m}^{3}\end{array}$} & \multicolumn{3}{|c|}{$\begin{array}{c}\text { Mix proportion (by } \\
\text { weight) }\end{array}$} & \multirow[t]{2}{*}{$\mathbf{w} / \mathbf{c}$} & \multirow[t]{2}{*}{ Sp } & \multirow{2}{*}{$\begin{array}{l}\text { Slump } \\
(\mathbf{m m})\end{array}$} & \multirow{2}{*}{$\begin{array}{c}\text { De- } \\
\text { moulded } \\
\text { density } \mathbf{~ k g} / \\
\mathbf{m}^{\mathbf{3}}\end{array}$} & \multirow{2}{*}{$\begin{array}{c}\text { Targeted } \\
\text { comp. st. } \\
\text { (28 days) } \\
\mathrm{MPa}\end{array}$} & \multirow{2}{*}{$\begin{array}{l}\text { Obtained } \\
\text { comp. st. (28 } \\
\text { days) MPa }\end{array}$} \\
\hline & & C & $\mathbf{S}$ & OPBC & & & & & & \\
\hline AS-1 & 350 & 1 & 0.80 & 1.65 & 0.60 & 1.71 & 20 & 1744 & 25.0 & 18.5 \\
\hline AS-2 & 350 & 1 & 1.22 & 2.43 & 0.80 & 1.71 & Coll. & 2215 & 25.0 & 10.5 \\
\hline AS-3 & 350 & 1 & 1.17 & 2.35 & 0.82 & 1.71 & Coll. & 2144 & 25.0 & 10.0 \\
\hline AS-4 & 450 & 1 & 0.80 & 1.65 & 0.60 & 1.71 & 0 & 2105 & 25.0 & 19.5 \\
\hline AS-5 & 450 & 1 & 1.22 & 2.43 & 0.80 & 1.71 & Coll. & 2155 & 25.0 & 11.5 \\
\hline AS-6 & 450 & 1 & 1.17 & 2.35 & 0.82 & 1.71 & Coll. & 2210 & 25.0 & 10.5 \\
\hline
\end{tabular}

Note: C-Cement, S-Sand, OPBC-Oil Palm Boiler Clinker, Coll.-Collapse, Sp-Super plasticizer (litre/100 kg cement)

28-day strength. Six mixes are enough for conclusion. The slump was less than $20 \mathrm{~mm}$ although the super plasticizer was used in all the mixes. Actually, the mix design procedure is shown in Short and Kinniburgh (1978) using artificial lightweight aggregates such as Leca, foamed slag, Aglite and Lytag.

Table 4 shows the mix orders ST- 1 to ST-4 based on the mix design for lightweight concrete suggested by Shetty (2008). Four mixes are enough for conclusion. The slump values were less than $10 \mathrm{~mm}$ and the demoulded densities were in the range of 1725 to $1855 \mathrm{~kg} / \mathrm{m}^{3}$. However, the obtained 28-day compressive strengths were in the range of $10.5 \mathrm{MPa}$ to 21.0MPa which were less than the targeted 28day strength.
Based on the above, the targeted designed strengths of OPBC concrete could not be achieved by employing these established methods. Hence it was concluded that the established methods such as ACI method for normal weight concrete and the methods in references Shetty (2008; Short and Kinniburgh, 1978) for lightweight concrete could not be adopted for the mix design of OPBC concrete. .

However, a large number of trials as shown in Table 5 were attempted to obtain the acceptable compressive strength of OPBC concrete. In these trials, different variations were considered such as mix proportion, cement content, w/c ratio and dosages of super plasticizer. Twenty one mixes were necessary for conclusion.

Table 4: Mix design for OPBC concrete according to the method mentioned in ref. (Shetty 2008)

\begin{tabular}{|c|c|c|c|c|c|c|c|c|c|c|}
\hline \multirow[t]{2}{*}{$\begin{array}{l}\text { Mix. } \\
\text { No. }\end{array}$} & \multirow[t]{2}{*}{$\begin{array}{l}\text { Cement } \\
\mathrm{kg} / \mathrm{m}^{3}\end{array}$} & \multicolumn{3}{|c|}{$\begin{array}{c}\text { Mix proportion (by } \\
\text { weight) }\end{array}$} & \multirow[t]{2}{*}{$\mathbf{w} / \mathbf{c}$} & \multirow[t]{2}{*}{ Sp } & \multirow[t]{2}{*}{$\begin{array}{l}\text { Slump } \\
(\mathbf{m m})\end{array}$} & \multirow{2}{*}{$\begin{array}{l}\text { Demoulded } \\
\text { density kg/ } \\
\mathbf{m}^{3}\end{array}$} & \multirow{2}{*}{$\begin{array}{c}\text { Targeted } \\
\text { comp. st. } \\
\text { (28 days) } \\
\mathrm{MPa}\end{array}$} & \multirow{2}{*}{$\begin{array}{c}\text { Obtained } \\
\text { comp. st. } \\
\text { (28 days) } \\
\mathrm{MPa}\end{array}$} \\
\hline & & C & $\mathbf{S}$ & ОРВС & & & & & & \\
\hline ST-1 & 350 & 1 & 0.73 & 1.47 & 0.55 & 1.70 & 10 & 1748 & 25.0 & 18.0 \\
\hline ST-2 & 350 & 1 & 1.34 & 2.68 & 0.70 & 1.71 & Coll. & 1855 & 25.0 & 10.5 \\
\hline ST-3 & 450 & 1 & 0.73 & 1.47 & 0.55 & 1.70 & 0 & 1725 & 25.0 & 21.0 \\
\hline ST-4 & 450 & 1 & 1.34 & 2.68 & 0.70 & 1.71 & Coll. & 1755 & 25.0 & 12.0 \\
\hline
\end{tabular}

Note: C-Cement, S-Sand, OPBC-Oil Palm Boiler Clinker, Coll.-Collapse, Sp-Super plasticizer (litre/100 kg cement) 
116 Mannan and Neglo

Table 5: Trial mix proportions of OPBC concrete

\begin{tabular}{|c|c|c|c|c|c|c|c|c|c|}
\hline \multirow{2}{*}{$\begin{array}{l}\text { Mix. } \\
\text { No. }\end{array}$} & \multirow{2}{*}{$\begin{array}{l}\text { Cement } \\
\mathrm{kg} / \mathrm{m}^{3}\end{array}$} & \multicolumn{3}{|c|}{$\begin{array}{c}\text { Mix proportion (by } \\
\text { weight) }\end{array}$} & \multirow{2}{*}{$\mathbf{w} / \mathbf{c}$} & \multirow{2}{*}{ Sp } & \multirow{2}{*}{$\begin{array}{l}\text { Slump } \\
(\mathbf{m m})\end{array}$} & \multirow{2}{*}{$\begin{array}{c}\text { Demoulded } \\
\text { density } \mathrm{kg} / \mathrm{m}^{3}\end{array}$} & \multirow{2}{*}{$\begin{array}{l}\text { Comp. strength } \\
\text { (28 days) MPa }\end{array}$} \\
\hline & & C & $\mathbf{S}$ & OPBC & & & & & \\
\hline M1 & 350 & 1 & 1.43 & 2.21 & 0.78 & $3 \%$ & 7 & 1801 & 19.5 \\
\hline M2 & 350 & 1 & 1.43 & 1.99 & 0.78 & $3 \%$ & 14 & 1798 & 10.0 \\
\hline M3 & 350 & 1 & 1.43 & 2.21 & 0.78 & $3 \%$ & 250 & 1716 & 20.0 \\
\hline M4 & 350 & 1 & 1.43 & 1.69 & 0.50 & $3 \%$ & 110 & 1937 & 16.5 \\
\hline M5 & 400 & 1 & 1.50 & 2.21 & 0.50 & 1.00 & 10 & 1948 & 38.5 \\
\hline M6 & 400 & 1 & 1.50 & 1.63 & 0.50 & 1.50 & 0 & 1925 & 30.0 \\
\hline M7 & 400 & 1 & 1.50 & 1.63 & 0.60 & 1.50 & 100 & 1868 & 33.0 \\
\hline M8 & 350 & 1 & 1.50 & 1.60 & 0.55 & 1.50 & 10 & 1870 & 27.0 \\
\hline M9 & 350 & 1 & 1.50 & 1.50 & 0.58 & 1.50 & 10 & 1932 & 23.0 \\
\hline M10 & 350 & 1 & 1.13 & 1.50 & 0.50 & 0.80 & 10 & 1804 & 28.0 \\
\hline M11 & 350 & 1 & 1.44 & 1.50 & 0.50 & 0.57 & 10 & 1845 & 31.0 \\
\hline M12 & 350 & 1 & 1.27 & 1.50 & 0.50 & 1.15 & 0 & 1845 & 27.0 \\
\hline M13 & 350 & 1 & 1.27 & 1.50 & 0.50 & 1.30 & 10 & 1846 & 27.0 \\
\hline M14 & 350 & 1 & 1.27 & 1.50 & 0.50 & 1.45 & 30 & 1845 & 27.0 \\
\hline M15 & 350 & 1 & 1.27 & 1.50 & 0.50 & 1.58 & 0 & 1844 & 27.0 \\
\hline M16 & 350 & 1 & 1.27 & 1.50 & 0.50 & 1.58 & 40 & 1845 & 27.0 \\
\hline M17 & 350 & 1 & 1.27 & 1.50 & 0.58 & 1.70 & 40 & 1845 & 27.0 \\
\hline M18 & 350 & 1 & 2.0 & 1.50 & 0.57 & 1.29 & 40 & 1931 & 32.5 \\
\hline M19 & 350 & 1 & 2.0 & 1.50 & 0.57 & 1.57 & 40 & 1946 & 34.0 \\
\hline M20 & 350 & 1 & 2.0 & 1.50 & 0.57 & 1.71 & 60 & 1943 & 34.5 \\
\hline M21 & 450 & 1 & 1.67 & 1.17 & 0.48 & 1.33 & 70 & 1980 & 35.5 \\
\hline
\end{tabular}

Note: C-Cement, S-Sand, OPBC-Oil Palm Boiler Clinker, Sp-Super plasticizer (litre/100 kg cement)

\section{Acceptable Mix Design for OPBC concrete}

The acceptable mix proportions with different ingredients are presented in Table 6 . These acceptable mixes are derived from Table 5 . The cement contents used were in the range of 350 to $450 \mathrm{~kg} / \mathrm{m}^{3}$ within the usual range values for lightweight concrete. For lightweight concrete, the amount of cement content specified is in the range of 285 to $510 \mathrm{~kg} / \mathrm{m}^{3}$ (Mindess, et al. 2003). Demoulded density observed here was in the range of 1845 to $1980 \mathrm{~kg} / \mathrm{m}^{3}$. The 28 -day compressive strengths obtained were in the range from 27 to $35 \mathrm{MPa}$ and are more than $17 \mathrm{MPa}$ suitable to be used as structural lightweight concrete. An insight of OPBC concrete is shown in Figure 3.

\section{CONCLUSIONS}

Based on the results of this study, the following conclusions are drawn.

The specific gravity for OPBC aggregates observed as 1.68 is in the range of lightweight aggregates. The bulk density of OPBC observed as $805 \mathrm{~kg} / \mathrm{m}^{3}$ is in the range of lightweight aggregate. The medium workability was obtained as indicated by $40 \mathrm{~mm}$ to $100 \mathrm{~mm}$ slump values as shown in acceptable mix design. The demoulded densities were in the range of 1845 to $1980 \mathrm{~kg} / \mathrm{m}^{3}$ which indicate lightweight concrete. The 28-day compressive strengths were in the range from 27 to $35 \mathrm{MPa}$ and were more than $17 \mathrm{MPa}$ suitable to be used as structural lightweight concrete. 
Table 6: Acceptable mix proportions of OPBC concrete

\begin{tabular}{|c|c|c|c|c|c|c|c|c|c|}
\hline \multirow{2}{*}{$\begin{array}{l}\text { Mix. } \\
\text { no. }\end{array}$} & \multirow{2}{*}{$\begin{array}{l}\text { Cement } \\
\mathrm{kg} / \mathrm{m}^{3}\end{array}$} & \multicolumn{3}{|c|}{$\begin{array}{l}\text { Mix proportion (by } \\
\text { weight) }\end{array}$} & \multirow[t]{2}{*}{$\mathbf{w} / \mathbf{c}$} & \multirow[t]{2}{*}{ Sp } & \multirow{2}{*}{$\begin{array}{l}\text { Slump } \\
(\mathbf{m m})\end{array}$} & \multirow{2}{*}{$\begin{array}{c}\text { Demoulded } \\
\text { density kg/ } \\
\mathbf{m}^{\mathbf{3}}\end{array}$} & \multirow{2}{*}{$\begin{array}{c}\text { Obtained comp. } \\
\text { st. (28 days) } \\
\text { MPa }\end{array}$} \\
\hline & & C & $\mathbf{S}$ & ОРВC & & & & & \\
\hline B-1 & 400 & 1 & 1.5 & 1.63 & 0.60 & 1.50 & 100 & 1868 & 33.0 \\
\hline B-2 & 350 & 1 & 1.27 & 1.5 & 0.50 & 1.58 & 40 & 1845 & 27.0 \\
\hline B-3 & 350 & 1 & 2 & 1.5 & 0.57 & 1.29 & 40 & 1931 & 32.5 \\
\hline B-4 & 350 & 1 & 2 & 1.5 & 0.57 & 1.57 & 40 & 1946 & 34.0 \\
\hline B-5 & 350 & 1 & 2 & 1.5 & 0.57 & 1.71 & 60 & 1943 & 34.5 \\
\hline B-6 & 450 & 1 & 1.67 & 1.17 & 0.48 & 1.33 & 70 & 1980 & 35.5 \\
\hline
\end{tabular}

Note: Sp-Super plasticizer (litre/100 kg cement)

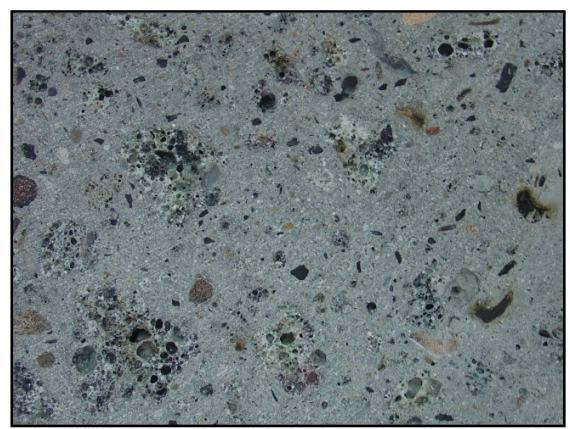

Fig. 3: OPBC concrete-an insight

\section{ACKNOWLEDGEMENTS}

The experimental investigation has been performed at Universiti Malaysia Sabah (UMS) and the authors express sincere thanks to $\mathrm{S}$. Zaini for contribution in work.

\section{REFERENCES}

BSI Document 92/17688. (1992). European Draft Standard Specification for lightweight Aggregates, CEN/TC154/SC5, Sub -Committee Lightweight Aggregates.

ENV-Euro Code No.2. (1992). Design of Concrete Structures Parts 1-4: The use of lightweight aggregates with closed structures.

Mannan, M. A. (2001). "A study on the use of oil palm shell in lightweight concrete", $\mathrm{PhD}$ Thesis, Universiti Malaysia Sabah, Sabah, Malaysia, 179 pages.
Mannan, M. A. and Ganapathy, C. (2004). "Concrete from an agricultural waste -oil palm shell (OPS)", Building and Environment, 39, 441-448.

Mindess D. Young J.F. and Darwin D. (2003). Concrete 2nd edition, Prentice Hall, United States of America.

MPOB (Malaysian Palm Oil Board), (2005). "A summary on the performance of the Malaysian oil palm industry2005" (online), http://econ.mpob.gov.my/ economy/summary latest05.htm.

Nontananandh, S. (1990). "Industrial waste utilisation as construction materials by chemical stabilisation", Ph. D Thesis. Department of Civil Engineering, Kyoto University, Japan, 347 pages.

Shetty, M. S. (2008). Concrete Technology: Theory and Practice, S Chand \& Company Itd, India, 624 pages.

Short, A. and Kinniburgh, W. (178). Lightweight Concrete, 3rd edition, Applied Science Publishers, London, 464 pages.

Tay, J-H. (1990). "Ash from Oil -Palm Waste as Concrete Material", Journal of Materials in Civil Engineering 2(2), $94-105$.

United State Department of Agriculture (USDA), "Production Estimates and Crop Assessment Division, Foreign Agriculture Services". 


\section{Mannan and Neglo}

(Online) http://www.wrm.org.uy/plantations/ material/oilpalm.html.

Wahid, M. B. (undated). "Malaysian Palm Oil Board (MPOB): Overview of the Malaysian oil palm industry 2005" (on-line) http://econ.mpob.gov.my/economy/ su_review 2005.htm, 